\title{
Short Communication: The physical and chemical properties of nipah (Nypa fructicans) frond as an alternative feed for ruminants in Indonesia
}

\author{
MUHAMMAD AFDAL", TEJA KASWARI, SAITUL FAKHRI, HENI SURYANI \\ Faculty of Animal Science, Universitas Jambi. Jl. Jambi-Muara Bulian, No. 15, Mendalo Darat, Jambi City 36122, Jambi, Indonesia \\ Te;//fax.: +62-741-582907. ‘email: m.afdal@unja.ac.id
}

Manuscript received: 23 July 2020. Revision accepted: 22 September 2020.

\begin{abstract}
Afdal M, Kaswari T, Fakhri S, Suryani H. 2020. Short Communication: The physical and chemical properties of nipah (Nypa fructicans) frond as an alternative feed for ruminants in Indonesia. Biodiversitas 21: 4714-4718. The aim of this study was to evaluate the physical and chemical properties, as well as the degradation of dry matter (DM) and organic matter (OM), of nipah (Nypa fructicans Wurmb.) frond, in view of its potency as an alternative source of feed. Samples of nipah frond were collected from the Sub-district of Geragai and Nipah Panjang, Indonesia, representing lowland brackish and coastal areas, respectively. All samples were explored to reveal their physical and chemical properties, degradation of DM and OM, and total gas production. The t test was applied to compare parameters between the Geragai and Nipah Panjang areas. There were no significant differences $(\mathrm{P}>0.05)$ in frond weight and leaf weight between the two sample locations. The length of frond and the length from base to first leaf of nipah was significantly different $(\mathrm{P}<0.05)$ between both locations. The number of leaves in one frond and the number of fruit in one bunch were highly significant different $(\mathrm{P}<0.01)$ between the two sample regions. The DM and OM degradation of nipah fronds and leaves were not significantly different $(\mathrm{P}>0.05)$. between Geragai and Nipah Panjang, while the DM and OM degradation of nipah leaves were also not significantly different $(\mathrm{P}>0.05)$. However, total gas production from the leaves and fronds were highly significantly different $(\mathrm{P}<0.01)$ between Geragai and Nipah Panjang. It can be summarized that the physical properties and chemical composition of the fronds and leaves of nipah in these areas are similar except for the length between base and the first leaf, the number of leaves, and the number of fruit in a single bunch, which were different. In terms of DM and OM degradation, there were no differences between the lowland brackish area and the coastal area, except for in terms of total gas production, which was significantly different between the two sample locations.
\end{abstract}

Keywords: Feed, gas, in vitro, Nypa fructicans, properties

\section{INTRODUCTION}

Nipah (Nypa fructicans Wurmb.) is a wild plant that grows along lowland and coastal areas in mangrove forests (Theerawitaya et al. 2014; Tomlinson 2016). Nipah originated in Asia and spread to Europe, Africa, and the Americas (Dransfield et al. 2008). Yuliana et al. (2019) reported that the nipah plant, with an Importance Value Index of $53.59 \%$, dominates the Calik riverbank in south Sumatra. Morphologically, the nipah plant looks similar to the oil palm or coconut tree, having long fronds with sticky leaves. nipah plants normally grow in areas where the river and seawater meet (Hossain and Islam 2015). Nipah grows well in the brackish environments near mangrove forests (Rozainah and Aslezaeim 2010). Nipah is classified under the Palmae family and grouped as a mangrove forest plant (Subiandono et al. 2011). Like other members of the Palmae family, nipah does not have a visible stem above the ground, instead of possessing an underground stem named a rhizome.

The nipah plant is widely distributed in South Asia, Southeast Asia, and Oceania (Tsuji et al. 2011). The largest natural nipah forest area in Indonesia is estimated to be approximately 700.000 ha (Subiandono et al. 2011). Traditionally, the nipah plant has many uses, including roofing material, the young leaves are used for cigarette wrappers or cooked rice wrappers, edible young seeds, and medicinal purposes, the dried petioles or stalks are used for firewood and brooms, as well as material for making ethanol or salt (Okugbo et al. 2012; Hossain and Islam 2015). Importantly, the chemical composition of nipah plants, including fronds and leaves, could be affected by the soil in which they grow. Geragai is a lowland area surrounded by brackish and sometimes salty water, depending on the tide, while Nipah Panjang is a coastal area always surrounded by salty water. Currently, there is no information available concerning the effect of salinity on nipah plant frond (NPF). Therefore, more studies are needed for investigating NPF in different soil salinities. This condition of water salinity could influence the chemical composition of NPF. Generally, the composition of nipah, particularly its fiber composition and physical properties, the degradation of DM and OM, and the total gas production that may be suitable for use as an alternative feed for ruminants (Negesse et al. 2009; Tamunaidu and Saka 2011).

Nipah plant material can potentially be used as an alternative source of feed for ruminants due to its high fiber content (Negesse et al. 2009; Tamunaidu and Saka 2011). The composition of fiber in the nipah frond is comparable 
to the composition of fiber in the oil palm frond (OPF). Studies have already been conducted concerning the use of OPF as a source of animal feed (Afdal et al. 2010; Suryani et al. 2017; Muthalib and Afdal 2018). However, there is limited information concerning the physical and chemical properties of nipah for its use as animal feed. Given the abundance of nipah in Indonesia, this plant may serve as an alternative source of feed, especially for ruminants. Therefore, the current study was conducted with the objective of evaluating the physical and chemical properties of the nipah frond, as well as the degradation of its $\mathrm{DM}$ and $\mathrm{OM}$ and total gas production, in order to investigate its potential as an alternative source of feed. The information generated from this study may be utilized in exploring potential applications of these fronds as ruminant feed.

\section{MATERIALS AND METHODS}

\section{Sample preparation and procedure}

The study sites were located in East Tanjung Jabung District, Jambi, Indonesia (latitude $0^{\circ} 53^{\prime}-1^{\circ} 41^{\prime}$ and longitude $103^{\circ} 23^{\prime}-104^{\circ} 31^{\prime}$ ) (Figure 1). The samples of nipah frond were collected from the Sub-district of Geragai, representing a lowland brackish area, and the Subdistrict of Nipah Panjang, representing a coastal area. Each individual frond sample was separated into frond and leaf. All samples were then transported to the Laboratory of Animal Nutrition, Faculty of Animal Husbandry, University of Jambi, Indonesia for further analysis.

\section{Properties evaluation}

Fresh samples were evaluated for morphological properties including number of leaves per frond, weight of the whole frond, weight of the leaves in one frond, length from tree base to first leaf, weight of the fronds without leaves, and the number of fruits per tree. Combined samples of whole fronds, as well as leaves only, from both sample areas, were separately chopped, sundried, and ground in order to pass through a 0.5 sieve in a Wiley mill. Chemical analysis was then performed separately for each sample from Geragai and Nipah Panjang.

\section{In vitro degradation of dry matter and organic matter and gas production}

In vitro degradation, including the degradation of DM and OM, was conducted following the procedure of Tilley and Terry (Tilley and Terry 1963) with slight modification. The degradation of DM and OM was investigated after 48 $\mathrm{h}$ incubation. In vitro gas technique (Mauricio et al. 1999) was applied to evaluate the total gas production during $48 \mathrm{~h}$ of incubation.

\section{Chemical and statistical analysis}

Proximate analysis, including DM, ash, OM, ether extract, crude protein, and crude fiber, was performed according to the procedure of AOAC (2005). Analysis of fiber, including acid detergent fiber and neutral detergent fiber, was done following the procedure of Van Soest (1963). All parameters were analyzed and compared between the two sample regions by using the t-test (SAS 2002).

\section{RESULTS AND DISCUSSION}

\section{Physical properties of nipah}

The morphologies of the nipah collected from Geragai and Nipah Panjang are presented in Table 1. Table 1 includes the weights of fronds (WF), weights of leaves (WL), lengths of fronds (LF), lengths from tree base to first leaves (LB), number of leaves in single fronds (NL), and number of fruit in single bunches (NF). There were significant differences detected in LF, LB, NL, and NF except for WF and WL.
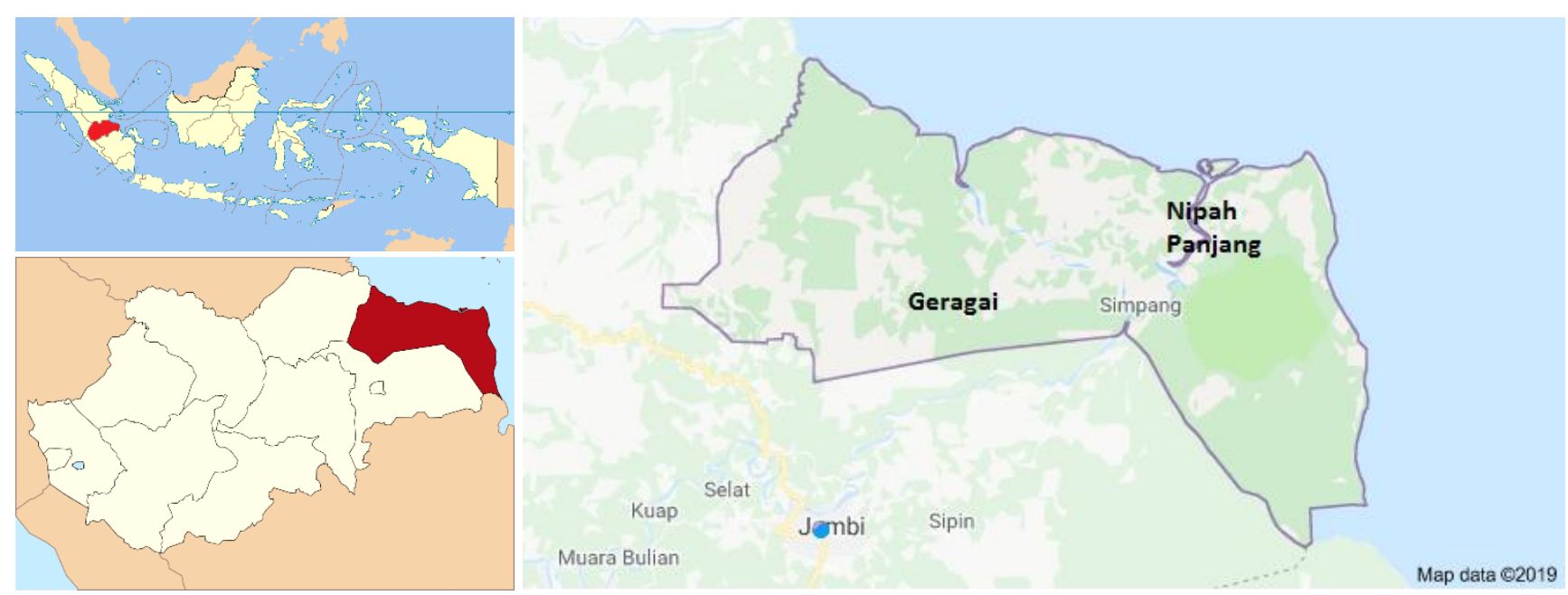

Figure 1. A map of study area in Geragai and Nipah Panjang of the East Tanjung Jabung District, Jambi, Indonesia 
Table 1. The Morphology of nipah in East Tanjung Jabung District, Jambi, Indonesia

\begin{tabular}{lccc}
\hline Characteristics & Geragai & $\begin{array}{c}\text { Nipah } \\
\text { Panjang }\end{array}$ & $\begin{array}{c}\text { p } \\
\text { (t test) }\end{array}$ \\
\hline Morphology & & & \\
Weight of frond (kg) & $5.47 \pm 4.05$ & $9.18 \pm 4.11$ & 0.1461 \\
Weight of leaf (kg) & $2.04 \pm 0.74$ & $2.10 \pm 0.13$ & 0.8522 \\
Length frond (m) & $5.25 \pm 1.67$ & $7.38 \pm 0.55$ & 0.0138 \\
Length from base to first & $0.80 \pm 0.46$ & $1.46 \pm 0.42$ & 0.0257
\end{tabular}

leaf $(\mathrm{m})$

The number of leaf (sheet) $120.67 \pm 13.74 \quad 66.17 \pm 5.81<0.0001$

\begin{tabular}{llll} 
Number of fruit in a bunch & $73.33 \pm 7.76$ & $28.58 \pm 11.67$ & 0.0005 \\
\hline
\end{tabular}

As shown in Table 1, the WF and WL of nipah growing in the two sample regions were not significantly different $(\mathrm{P}>0.05)$. However, the WF and WL in Nipah Panjang were slightly heavier than those in Geragai. The WF was $5.47 \pm 4.05$ and $9.18 \pm 4.11 \mathrm{~kg}$ for Geragai and Nipah Panjang, respectively. This phenomenon might be due to the effect of more salinity in the soil of Nipah Panjang, owing to its status as a coastal area. Salinity influences the plant turgor structure, for example, accelerating root lignification (Haryadi and Yahya 1998). Rhodes and Nadolska-Orczyk (2001) added that salinity and water deficits influence osmotic adjustments and then restrict dehydration and facilitate turgor maintenance. Of note, these changes might affect plant morphology. Tamunaidu and Saka (2011) reported that the $\mathrm{Na}^{+}$ion contributes up to $2 \%$ of the WF and $0.4 \%$ of the weight of the pinnae.

The LF and LB of nipah were significantly different $(\mathrm{P}<0.05)$ between samples from Geragai and Nipah Panjang (Table 1). The LFs were $5.25 \pm 1.67$ and $7.38 \pm$ $0.55 \mathrm{~m}$ for plants growing in Geragai and Nipah Panjang, respectively, while the LBs were $0.80 \pm 0.46$ and $1.46 \pm$ $0.42 \mathrm{~m}$, respectively. The LFs in these experiments were shorter than those observed in a previous study by Teo et al. (2010) who reported that the frond of nipah palm can grow up to $10 \mathrm{~m}$. Mantiquilla et al. (2019) reported nipah leaves of 5 to $9 \mathrm{~m}$ length and less than 12 pinnate leaves on each stem. The LF and LB are indicators of the growth rate of nipah. The results of our experiments showed that fronds appeared longer in the high salinity area of Nipah Panjang compared to the low salinity area of Geragai. It is possible that the growth rate is affected by the salinity of the soil in which nipah is grown. These results are in contrast to Hutahaean et al. (1999) who found that good growth rates of some species of mangrove plants occur in the low salinity soils.

The NL in one frond and the NF were highly significantly different $(\mathrm{P}<0.01)$ between plants grown in Geragai and Nipah Panjang. The NL per frond in Geragai was almost two-fold that of Nipah Panjang. This could be due to the differences in soil salinity between the two places. Geragai is a low tide area in which the water conditions are always changing depending upon the tide from the sea, while Nipah Panjang is a coastal area in which the water is always salty. These conditions likely affect the salinity of the soil, and thus influence the growth of the nipah tree. More physiological studies are needed concerning the effects of soil salinity on nipah morphology. Some reports state that increased salinity influences the morphology of plants (Arunothai and Brix 2009; Chartzoulakis 2005). In fact, increased salinity has been shown to influence leaf area of Echium amoenum Fisch. \& Mey (Elham et al. 2011), thus the NL and NF of nipah may be similarly affected.

\section{Chemical composition}

Table 2 shows the chemical composition of nipah leaves and nipah fronds from both areas. These data include the composition of ash, ether extract (EE), crude protein $(\mathrm{CP})$, crude fiber (CF), acid detergent fiber (ADF), and neutral detergent fiber (NDF). The ash content of nipah leaf was $7.23 \%$ and $6.15 \%$ in Geragai and Nipah Panjang, respectively, while the ash content of nipah whole frond was $7.24 \%$ and $4.76 \%$, respectively. These results were higher than previous results; the ash content of nipah frond from Nigeria was demonstrated to be $4.06 \%$ (Akpakpan et al. 2012). High observed ash content is desirable as it is a good source of salt material. nipah salt can be produced from the old petiole (Subiandono et al. 2011). The ether extract content is somewhat low, CP content is low, and CF content is fairly high. Based on its chemical composition, including low $\mathrm{CP}$ and high $\mathrm{CF}$, nipah may potentially be used as a feed source for ruminants, as these animals are usually able to utilize or digest this fibre in the rumen. However, the high content of mineral in nipah should be considered when preparing rations. Some studies have reported that the composition of fiber in rations, including NDF, ADF, cellulose, and hemicellulose, was a crucial factor for ruminants (Alsersy et al. 2015; Harper and McNeill 2015; Jung and Phillips 2010; Girard and Dupuis 1988).

\section{In vitro degradation}

The in vitro degradation of DM and OM of leaves and fronds of nipah can be seen in Table 3. The results show that there was no significant difference $(P>0.05)$ in the in vitro degradation of $\mathrm{DM}$ and $\mathrm{OM}$ of leaves and fronds between samples from Geragai and Nipah Panjang. The degradation of DM for fronds was between $26.71 \%$ and $28.26 \%$, while the degradation of OM was between $25.01 \%$ and $26.48 \%$. nipah is an important, underutilized plant growing in Indonesia that lacks corresponding scientific literature.

Table 2. The chemical composition of nipah in East Tanjung Jabung District, Jambi, Indonesia

\begin{tabular}{lcccc}
\hline \multirow{2}{*}{ Nutrient } & \multicolumn{2}{c}{ Leaf } & \multicolumn{2}{c}{ Frond } \\
\cline { 2 - 5 } & Geragai & $\begin{array}{c}\text { Nipah } \\
\text { Panjang }\end{array}$ & Geragai & $\begin{array}{c}\text { Nipah } \\
\text { Panjang }\end{array}$ \\
\hline Dry matter (\%) & 92.25 & 92.91 & 90.83 & 89.66 \\
Ash (\%) & 7.23 & 6.15 & 7.24 & 4.76 \\
Ether extract (\%) & 2.93 & 1.94 & 1.56 & 5.24 \\
Crude protein (\%) & 5.85 & 4.82 & 3.07 & 6.14 \\
Crude fiber (\%) & 28.40 & 23.15 & 31.53 & 25.83 \\
ADF (\%) & 42.72 & 50.48 & 46.42 & 49.1 \\
NDF (\%) & 53.42 & 50.95 & 62.00 & 63.57 \\
\hline NDF
\end{tabular}

Note: ADF: acid detergent fiber, NDF: neutral detergent fiber 
Table 3. The DM and OM degradation and gas production of nipah Leaf and frond in Geragai and Nipah Panjang Sub-districts, East Tanjung Jabung District, Jambi, Indonesia

\begin{tabular}{lccc}
\hline In vitro study & Geragai & $\begin{array}{c}\text { Nipah } \\
\text { Panjang }\end{array}$ & $\begin{array}{c}\text { p } \\
\text { (t test) }\end{array}$ \\
\hline Frond & & & \\
$\quad$ Dm degradation (\%) & $26.71 \pm 3.21$ & $28.26 \pm 3.87$ & 0.5606 \\
$\quad$ Om degradation (\%) & $25.01 \pm 3.19$ & $26.48 \pm 3.86$ & 0.5769 \\
Leaf & & & \\
$\quad$ Dm degradation (\%) & $25.15 \pm 1.84$ & $23.28 \pm 2.99$ & 0.9869 \\
$\quad$ Om degradation (\%) & $23.38 \pm 1.84$ & $21.50 \pm 2.97$ & 0.9650 \\
Gas production & & & \\
$\quad$ Leaf (mL/g) & $27.34 \pm 1.32$ & $10.69 \pm 2.39$ & $<0.0001$ \\
$\quad$ Frond (mL/g) & $42.42 \pm 5.77$ & $8.00 \pm 3.55$ & $<0.0001$ \\
\hline
\end{tabular}

However, its composition and other characteristics are similar to the oil palm and, thus, results are compared with the oil palm for reference. The potential degradability of nipah frond was significantly lower $(\mathrm{P}<0.01)$ than that of the OPF (Abdalla 2001). However, nipah's degradability was higher than the degradation of DM and OM of fermented OPF studied by Wajizah et al. (2015). Wajizah et al. reported that the DM degradation of fermented OPF was $20.95-25.23 \%$, while the OM degradation was 17.21 $17.88 \%$. The degradation of $\mathrm{DM}$ or OM might be influenced by the ADF content of nipah. The quality of forage also depends on the crude fiber content, and ADF limits the digestibility of forage (Linn and Carla 1997). Therefore, the DM and OM degradations of leaves and fronds from both Nipah Panjang and Geragai depends on the ADF content of nipah leaves and fronds in those areas.

The in vitro gas production from nipah leaves and fronds can be seen in Table 3. The total gas production from incubation of leaves and fronds was highly significant different $(\mathrm{P}<0.01)$ between samples from Geragai and Nipah Panjang. The total gas production from leaves and fronds was much lower in samples from Nipah Panjang compared to Geragai. As scientific information concerning the gas production of nipah is lacking, the gas production of the oil palm was used for comparison. A study of total gas production from oil palms in Malaysia resulted in 163.5 and $147.5 \mathrm{~mL} / \mathrm{g}$ for the leaves and fronds, respectively (Islam et al. 2000). Another report demonstrated that the total gas production from oil palm petioles was $90.76 \mathrm{~mL} / \mathrm{g}$ (Suryadi et a. 2009). The gas production from nipah leaves and fronds in this study were lower than these results from OPFs. These results may indicate a lower fermentation activity in nipah compared to oil palm. Additionally, the gas production from leaves and fronds in samples from Geragai appeared much higher than in samples from Nipah Panjang, possibly due to the effects of the different environments.

It can be concluded that the chemical compositions of nipah fronds and leaves are similar to that of OPFs and leaves. Additionally, the DM and OM degradations, as well as the in vitro gas production, of nipah fronds and leaves was similar to OPF. Hence, nipah fronds and leaves could potentially be used as an alternative feed for ruminants.

\section{ACKNOWLEDGEMENTS}

We really appreciate to University of Jambi for funding this project with contract number of 2624/UN21.17/LT/ 2018 dated 17 May 2018.

\section{REFERENCES}

Abdalla SA. 2001.Oil Palm And Nipah Frond Silages And Their Utilization by Sheep. [Dissertation]. Universiti Putra Malaysia, Serdang Malaysia

Afdal M, Darlis D, Syarif S, Kasim A. 2010. The effect of oil Palm Petiole in total mixed diet on the consumption and digestibility in Bali cows (Bos sondaicus). Proceedings of the British Society of Animal Science and the Agricultural Research Forum, Belfast, UK Volume 1, Issue 1, p. 209. DOI: 10.1017/S2040470010003g523.

Akpakpan AE, Ukana DA, Ime BO. 2012. Evaluation of physicochemical properties and soda pulping of Nypa fruticans frond and petiole. Elixir Appl Chem 45: 7664-7668.

Alsersy H, Salem AZM, Borhami BE, Olivares J, Gado HM, Mariezcurrena MD, Yacuot $\mathrm{MH}$, Kholif AE, El-Adawy M, Hernandez SR. 2015. Effect of Mediterranean saltbush (Atriplex halimus) ensilaging with two developed enzyme cocktails on feed intake, nutrient digestibility and ruminal fermentation in sheep. Anim Sci J 86: 51-58. DOI: 10.1111/asj.12247

AOAC [Association of Official Analytical Chemists]. 2005. Official Methods of Analysis. 18th ed. In: Horwitz W, Latimer JrGW. (eds.). AOAC International, USA

Arunothai J, Brix H. 2009. Effects of $\mathrm{NaCl}$ salinity on growth, morphology, photosynthesis and proline accumulation of Salvinia natans. Aquat Bot 91 (3): 181-186.

Chartzoulakis KS. 2005. Salinity and olive: Growth, salt tolerance, photosynthesis and yield. Agric Water Manag 78: 108-121.

Dransfield J, Uhl NW, Asmussen CB, Baker WJ, Harley MM, Lewis CE. 2008. Genera Palmarum: The Evolution and Classification of Palms. Royal Botanic Gardens, Kew.

Elham R, Sepanlou MG, Badi HAN. 2011. The effect of salinity on the growth, morphology and physiology of Echium amoenum Fisch. \& Mey. Afr J Biotechnol 10 (44): 8765-8773.

Girard V, Dupuis G. 1988. Effect of structural and chemical factors of forages on potentially digestible fiber, intake, and true digestibility by ruminants. Can J Anim Sci 68: 787-799.

Harjadi, SS; S. Yahya. 1998, Fisiologi Stres Tanaman. PAU IPB, Bogor. [Indonesian]

Harper KJ, David M. McNeill 2015. The role iNDF in the regulation of feed intake and the importance of its assessment in subtropical ruminant systems (the role of iNDF in the Regulation of Forage Intake). Agriculture 5: 778-790. DOI: 10.3390/agriculture5030778

Hossain MF, Islam MA. 2015. Utilization of mangrove forest plant : nipa palm (Nypa fruticans Wurmb). Am J Agric For 3: 156-160. DOI: 10.11648/j.ajaf.20150304.16.

Hutahaean EE, Kusmana C, Dewi HR. 1999. Study on growth capability of mangrove forest seedling of Rhizophora mucronata, Bruguiera gymnorrhiza and Avicennia marina species on various levels of salinity. Jurnal Manajemen HutanTropika 5 (1): 77-85. [Indonesian]

Islam M, Dahlan I, Rajion MA, Jelan ZA.. 2000. Productivity and nutritive values of different fractions of oil palm (Elaeis guineensis) frond. Asian-Aus J Anim Sci 13 (8): 1113-1120.

Jung HG, Phillips RL. 2010. Putative seedling ferulate ester ( $s f e$ ) maize mutant: morphology, biomass yield, and stover cell wall composition and rumen degradability. Crop Sci 50: 403-418.

Linn J, Carla K. 1997. The Effects of Forage Quality on Performance and Cost of Feeding Lactating Dairy Cows. University of Minnesota, Department of Animal Science, St. Paul, Minnesota, U.S.A.

Mantiquilla JA, Salmasan SFD, Obelidhon MKA, Abad RG. 2019. Nutrient status of nipa (Nypa fruticans Wurmb.) in selected areas of Mindanao, the Philippines. Banwa B. 14: art012. http://ojs.upmin.edu.ph/index.php/banwa-b/article/view/481.

Mauricio RM, Mould FL, Dhanoa MS, Owen E, Channa KS, Theodorou MK. 1999. A semi-automated in vitro gas production technique for ruminant feedstuff evaluation. Anim Feed Sci Tech 79: 321-330. 
Muthalib RR, Afdal M. 2018. Effect of oil palm frond treated with ammonia on carcass traits and meat chemical composition of Bali bulls-Indonesia. Iraqi J Vet Sci 32 (1): 57-60.

Negesse T, Makkar, HPS, Becker K. 2009. Animal feed science and technology nutritive value of some non-conventional feed resources of Ethiopia determined by chemical analyses and an in vitro gas method. Anim Feed Sci Technol 154: 204-217. DOI 10.1016/j.anifeedsci.2009.09.010

Okugbo OT, Usunobun U, Esan A, Adegbegi JA, Oyedeji JO, Okiemien CO. 2012.A review of Nipapalm as a renewable energy source in Nigeria. Res J Appl Sci Eng Technol 4: 2367-2371.

Rhodes D, Nadolska-Orczyk A. 2001. Plant Stress Physiology. John Wiley \& Sons, New York. DOI: 10.1038/npg.els.0001297.

Rozainah MZ, Aslezaeim N. 2010.A demographic study of a mangrove palm, Nypa fruticans. Sci Res Essays 5 (24): 3896-3902.

SAS. 2002. SAS 9.1.3 Portable. SAS 9.1 for windows, SAS Institute Inc, Cory 27513, USA.

Subiandono E, Heriyanto NM, Karlina E. 2011. Potensi nipah (Nypa fruticans (Thunb.) Wurmb.) sebagai sumber pangan dari hutan mangrove. Buletin Plasma Nutfah 17 (1): 54-60. [Indonesian]

Suryadi S, Afdal M, Latief A. 2009. Pengaruh penggantian rumput dengan pelepah sawit ditinjau dari segi kecernaan dan fermentabilitas secara in vitro gas. Jurnal Ilmiah ilmu-ilmu Peternakan 12 (1): 29-34. [Indonesian]

Suryani H, Zain M, Ningrat RWS, Jamarun N. 2017. Effect of dietary supplementation based on an ammoniated palm frond with direct-fed microbials and virgin coconut oil on the growth performance and methane production of Bali Cattle. Pak J Nutr 16 (8): 599-604.
Tamunaidu P, Saka S. 2011. Chemical characterization of various parts of nipa palm (Nypa fruticans). Ind Crops Prod. 34, 1423-1428. DOI: 10.1016/j.indcrop.2011.04.020.

Teo S, Ang WF, Lok AFSL, Kurukulasuriya BR, Tan HTW. 2010.The status and distribution of the nipah, Nypa fructicans Wurmb (Arecaceae). Nat Sing 3: 45-52.

Theerawitaya C, Samphumphaung T, Cha-um S, Yamada N, Takabe T. 2014. Responses of nipa palm (Nypa fruticans) seedlings, a mangrove species, to salt stress in pot culture. Flora 209 (10): 597-603.

Tilley JMA, Terry RA. 1963. A two-stage technique for the in vitro digestion of forage crops. J Br Grassland Soc 18: 104-111.

Tomlinson PB. 2016. The Botany of Mangroves. $2^{\text {nd }}$ ed. Cambridge University Press, Cambridge, UK

Tsuji K, Ghazalli MNF, Ariffin Z, Nordin MS, Khaidizar MI, Dulloo ME. 2011. Biological and ethnobotanical characteristics of nipa palm (Nypa fructicans Wurmb.): A review. Sains Malaysiana 40 (12): 1407-1412.

Van Soest PJ. 1963. Use of detergents in the analyses of fibrous feeds. II A rapid method for the determination of fiber and lignin. J Assoc Official Agric Chem 46: 829-835.

Wajizah S, Samadi S, Usman Y, Mariana E. 2015. Evaluasi nilai nutrisi dan kecernaan in vitro pelepah kelapa sawit (oil palm fronds) yang difermentasi menggunakan Aspergillus niger dengan penambahan sumber karbohidrat yang berbeda. Jurnal Agripet 15 (1): 13-19. [Indonesian]

Yuliana E, Hewindati YT, Winata A, Djatmiko WA, Rahadiati A. 2019. Diversity and characteristics of mangrove vegetation in Pulau Rimau Protection Forest, Banyuasin District, South Sumatra, Indonesia. Biodiversitas 20: 1215-1221. 